\section{Clinical Implications of Early Molecular Diagnosis in Lung Cancer- brief review}

\author{
Claudiu-Eduard Nistor* and Camelia Stanciu-Găvan \\ Department of Thoracic Surgery, University of Medicine and Pharmacy “Carol Davila” Bucharest, \\ Central Military Emergency University Hospital "Carol Davila”, , Bucharest 010825, Romania
}

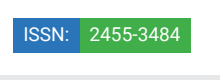

DOI:
Received: 07 May, 2020

Accepted: 16 May, 2020

Published: 18 May, 2020

*Corresponding author: Claudiu-Eduard Nistor, Department of Thoracic Surgery, University of Medicine and Pharmacy "Carol Davila” Bucharest, Central Military Emergency University Hospital “Carol Davila”, , Bucharest 010825, Romania,

E-mail: NISTOR-ncd58@yahoo.com

https://www.peertechz.com

Check for updates

\section{Introduction}

Lung cancer is a major issue in oncology pathology worldwide. According to the WHO, this disease is the number one cause of death in both men and women worldwide [1]. Worldwide The countries with the highest incidence of lung cancer meet in Polynesia and Hungary [2]. in Europe in 2018 According to the data provided by GLOBOCAN, the incidence of lung cancer was 470,039 new cases, of which 311,843 men and 158196 women [3]. The highest incidence was in Hungary, Austria, Germany, Slovenia, Latvia, Romania, the last places being Portugal, Malta, Lichtenstein [4]. For the correct analysis of the survival rate of patients diagnosed with lung cancer, the tumor stage (microcellular lung cancer and non-microcellular lung cancer) were considered; histopathological type (adenocarcinoma, squamous cell carcinoma, neuroendocrine lung tumors - small cell carcinoma, carcinoid; type of treatment (surgical, surgery-chemotherapy, surgery-radiotherapy, surgery-chemo-radiotherapy) [5]. Advanced lung cancer has an extremely poor prognosis, with a 5-year survival of only $5 \%$ [6]. An early diagnosis of lung cancer is needed to increase survival. A rapid personalized diagnosis (molecular, imaging, anatomopathological, immunohistochemical) is required in order to initiate an early personalized treatment [7]. After establishing the personalized diagnosis, the therapeutic attitude in the case of lung cancer the treatment can be started [8]. In this context, Molecular diagnosis of lung cancer can be made in the early stages of the disease.

The authors have a significant research activity in the early detection of tumor markers and the development of stochastic sensors. They participated in research projects: $2014-2017$ PN II, 22/2014, Multimode Microsensors based on micro and nano-structural materials with applications in biomedical analysis; 2018 - in progress - Program 4 - Fundamental and Frontier Research - "Complex Border Research Projects PCCF type" project number PN-III-P4-ID-PCCF-2016-0006, in Romania. Latest publication in the field - A Screening Test for Early Diagnosis of Microcellular Bronchopulmonary Cancer-Pilot Study; Claudiu-Eduard Nistor, Raluca-Ioana Stefan-van Staden, Adrian Vasile Dumitru and Camelia Stanciu Gavan; Journal of Clinical Medicine; J. Clin. Med. 2020, 9, 76; two:10.3390/jcm9010076 [9].

\section{Profiles of serum tumor markers for lung cancer groups}

Examination of tumor markers in the blood is much more affordable and more easily accepted by patients. These examinations are very useful to doctors for patients with suspected lung cancer. Early personalized diagnosis plays a very important role in early personalized treatment. The onset of personalized treatment differs depending on the histopathological type of the tumor. Thus, for some tumors the therapeutic regimen begins with surgical treatment, while other tumors begin with chemotherapy. Therapeutic efficacy is followed serologically much more easily than imaging followup.

\section{Profile of serum tumor markers for adenocarcinoma: CYFRA 21-1, CEA, P53, cytokeratin 19 (CK19).}

CYFRA 21-1 [cytokeratin fragment 19 (CK19)] is found in almost all of the lung adenocarcinomas have been tested and has more sensitivity and specificity compared to other biomarkers [10]. Cytokeratins, in particular fragment 19 , is an epithelial tissue protein, considered to be an ideal candidate for the detection of carcinoma [10-12]. The normal serum level of cytokeratingin 19 is about $3.3 \mathrm{ng} / \mathrm{ml}[13,14]$. 
CEA is not a specific tumor marker for lung cancer, but together with other markers it can provide informations. There has been a higher increase in serum levels in Non-small cell lung cancer (NSCLC) $[10,15]$. Normal EAA values are $3.8 \mathrm{ng} / \mathrm{ml}$ [10].

The mutation of the TP53 tumor suppressor gene occurs in Non-small cell lung cancer in 34\% of smokers patients with NSCLC [16]. The presence of this protein suggests resistance to chemotherapy [17]. TP53 detection is realised by FISH technique [18].

Profile of serum tumor markers for squamous cell carcinoma: CYFRA 21-1, squamous cell carcinoma-associated antigen (SCC) and Thioredoxin (Trx).

CYFRA 21-1 in the literature of speciality is specified to be the highest values together with levels of CEA with serum squamous cell carcinoma (SCCA) which characterizes the squamous lung cancer [19].

SCCA - squamous cell carcinoma-associated antigen - is protease serum inhibitors, is associated with the emergence and development of squamous cell carcinoma. It has very high values and is closely related to the prognosis of squamous lung cancer. [20]. The presence of the SCCA marker at the onset of the disease may suggest the diagnosis [21].

Thioredoxin (Trx) - is a protein that is very important in the redox process related to the lung tumor, in the peripheral blood under oxidative stress conditions [22]. The presence of this marker is interpreted alongside of SCCA, CYFRA21-1 and CEA [19].

Profile of serum tumor markers for small cell lung carcinoma (SCLC): Very high NSE, Thioredoxin (Trx), chromogranin A (CgA), synaptophysin, peptide releasing gastrin (ProGRP), ferritin.

NSE- Neuron-specific enolasis - is the tumor marker representative of long cell carcinoma (SLC). Its values have a strong correlation between the increased percentage of NSE and the stage of the disease [23].

Thioredoxin (Trx) - Has the highest values in small cell lung carcinoma in peripheral blood [19]

Chromogranin A (CHGA) - It is a marker specific to neuroendocrine tumors, which exhibit elevated levels in small cell lung cancer [24].

Synaptophysin (SYP) is a tumor marker specific to neuroendocrine tumors [24].

Peptide that releases gastrin (ProGRP) - It is a neuropeptide that occurs in neuroendocrine cells outside the stomach, being specific to neuroendocrine tumors [25]. Normal values for an adult are $<60 \mathrm{ng} / \mathrm{L}$, with a higher concentration in smokers [23]. In patients with small cell lung carcinoma this marker has very high values.

Serum ferritin is an iron storage protein that occurs in serum and some biological fluids of the body [26]. Although the mechanism of occurrence of very high levels is not known, in small cell lung carcinoma (SCLC) and metastatic cancers we experience very high levels of serum ferritin [27]. The average survival time of patients with low serum ferritin was found to be longer than that of high levels [26].

\section{Profile of typical/atypical carcinoid tumor serum: chromogranin A (CgA), neuron-specific enolase (NSE), Urinary into 5-hydroxyindoleacetic acid (5-HIAA)}

Chromogranin A (CHGA) - It is the most sensitive and convenient marker of neuroendocrine tumors, especially for bronchopulmonary carcinoid tumors [28]. It is an amino acid glycoprotein secreted by neuroendocrine cells [29]. The increased level predicts a generally poor prognosis of survival. It is a tumor marker used for monitoring therapeutic efficiency [30].

Neuron-specific enolase (NSE) -is an enzyme expressed by cells of neural origin and weakly different cells, reflecting the presence of high-grade disease and the increases reflect a high aggressiveness of the tumor [28]. It is a marker with elevated values in bronchopulmonary carcinoid but is not specific to this disease [31].

Urinary and plasma 5-hydroxyindoleacetic acid (5HIAA) - It is a metabolite of serotonin that is excreted in the urine in tumors that secrete serotonin [28]. It was one of the first markers used to diagnose neuroendocrine tumours pulmonary carcinoid and to monitor treatment response [32]. Plasma 5-HIAA measurement has been shown to correlate well with 5-HIAA urinary, and blood sampling is preferred by patients than in 24-hour urine collections [33,34].

Urinary serotonin and plasma - is a biogenic amine synthesized from the essential amino acid tryptophan [35]. Normally a small amount is found in the plasma [35]. Serotonin is detected in increased amounts in blood and urine tests [33].

\section{Discussion}

Clinical Implications of Early Molecular Diagnosis in Long Cancer leads to a cascade of investigations in order to make a personalized diagnosis. After establishing the personalized diagnosis, a personalized treatment is required. Following the thorough analysis of the literature, we concluded that the following steps are necessary:

Molecular diagnosis of bronchopulmonary cancer is based on a molecular profile, by examining several circulating analytes, most serological, but also from other biological fluids. Examination of a single analyte for molecular diagnosis shall not be recommended. The association of the results of the analytes (hormones, biologically active substances and tumor marker) established for each diagnostic profile, gives the necessary information. The role of these analyses is to detect the disease at an early stage, increasing life expectancy by initiating effective personalised treatment, reducing hospital costs and social reintegration of patients. 
$\checkmark$ Screening of the population with risk factors, by detection of tumor markers - Increased morbidity and mortality among the population with lung cancer - the 1st place in the world in neoplastic diseases, leads us to find new ways of screening the population. So, such a process is required for smokers and other people with risk factors.

$\checkmark$ Imaging investigations used for the detection of lung tumors; biological sampling of tumor formations - the high level of these tumor markers causes additional imaging investigations by pulmonary X-rays, tomography computer, PET-CT. Tumor formations detected imaging are subsequently biopsied by various invasive methods: bronchoscopy, guided imaging punctures, thoracoscopies, in order to confirm histopathological diagnosis.

$\checkmark$ Histopathological examination - remains the main analysis for the diagnosis of certainty of bronchopulmonary cancer. Biological samples obtained from tumor tissues by biopsy and/or cytology are necessary to the histopathologist to establish the personalized diagnosis and to direct the therapists - surgeon and oncologist - to apply the effective personalized therapeutic attitude.

$\checkmark$ The role and place of the Thoracic Surgery Surgeon is essential both in diagnosis and in therapeutic attitude. Together with the members of the oncology committee, first-line therapeutic conduct will be established where the role of the thoracic surgeon is essential in determining the surgical opportunity. Our experience is highlighted in the specialized work.

$\checkmark$ Control of the therapeutic efficiency of personalized treatment - can be achieved by analyzing markers from biological fluids, followed by imaging investigations.

Predicting - Increased life expectancy among the population with bronchopulmonary cancer can be achieved through screening, with early detection of bronchopulmonary cancer. This method can initiate effective custom treatment schemes.

\section{References}

1. OMS - World Health Organization: Cancer. Link: https://bit.ly/2X8sFXc

2. WHO (2018) Europe. Link: https://bit.ly/2TjhkCK

3. Ferlay J, Ervik M, Lam F, Colombet M, Mery L, et al. (2018) Global Cancer Observatory: Cancer Today. Lyon, France: International Agency for Research on Cancer. Link: https://bit.ly/36aJzbV

4. Statistics Explained. Link: https://bit.ly/3cLtJHa

5. Lu T, Yang X, Huang Y, Zhao M, Li M, et al. (2019) Trends in the incidence, treatment, and survival of patients with lung cancer in the last four decades. Cancer Manag Res 11: 943-953. Link: https://bit.ly/2WDbw90

6. De Groot PM, Wu CC, Carter BW, Munden RF (2018) Review Article The epidemiology of lung cancer. Translational Lung Cancer Res 7: 220-233. Link: https://bit.ly/2XaFdN
7. Caplin ME, Baudin E, Ferolla P, Filosso P, Garcia-Yuste M, et al. (2015) Pulmonary neuroendocrine (carcinoid) tumors: European Neuroendocrine Tumor Society expert consensus and recommendations for best practice for typical and atypical pulmonary carcinoids. Ann Oncol 26: 1604-1620. Link: https://bit.ly/2TfguXk

8. Niederhuber JE, Armitage JO, Doroshow JH, Kastan MB, Tepper JE (2014) Abedolff's clinical oncology. $5^{\text {th }}$ edn Churchill Livingstone, an imprint of Elsevier Inc. Link: https://bit.ly/3cINRcP

9. Nistor, CE, Staden RS, Dumitru AV, Gavan CS (2020) A Screening Test for Early Diagnosis of Microcellular Bronchopulmonary Cancer-Pilot Study. J Clin Med 9: 76. Link: https://bit.ly/3cludxR

10. Amir Roointana, Tanveer Ahmad Mirb,e,j,k, Shadil Ibrahim Wanic, ...\& all,; Early detection of lung cancer biomarkers through biosensor technology: A review; Journal of Pharmaceutical and Biomedical Analysis 164 (2019) 93-103 https://doi.org/10.1016/j.jpba.2018.10.017

11. Barillo JL, Silva CT, Silva PS (2018) Increased Cytokeratin 19 Fragment Levels Are Positively Correlated with Adenosine Deaminase Activity in Malignant Pleural Effusions from Adenocarcinomas. Hindawi Disease Markers 2018 2609767. Link: https://bit.ly/2TapYDt

12. Dal Bello MG, Filiberti RA, Alama A, Orengo AM, Mussap M, et al. (2019) The role of CEA, CYFRA21-1 and NSE in monitoring tumor response to Nivolumab in advanced non-small cell lung cancer (NSCLC) patients. J Transl Med 17: 74 Link: https://bit.ly/2ycji0d

13. Zissimopoulos A, Stellos K, Permenopoulou V, Petrakis G, Theodorakopoulos $P$, et al. (2007) The importance of the tumormarker CYFRA 21-1 in patients with lung cancer after surgery or chemotherapy. Hell J Nucl Med 10: 62-66. Link: https://bit.ly/2z9qLxv

14. Ye F, Shi M, Huang $Y$, Zhao S (2010) Noncompetitive immunoassay for carcinoembryonic antigen in human serum by microchip electrophoresis forcancer diagnosis. Clin Chim Acta 411: 1058-1062. Link: https://bit.ly/2TfhRoW

15. Zhang Y, Han CY, Duan FG, Fan XX, Yao XJ, et al. (2019) p53 sensitizes chemoresistant non-small cell lung cancer via elevation of reactive oxygen species and suppression of EGFR/PI3K/AKT signalling. Cancer Cell Int 19 188. Link: https://bit.ly/3fZoy8B

16. Gupta SC, Hevia D, Patchva S, Park B, Koh W, et al. (2012) Upsides and downsides of reactive oxygen species for cancer: the roles of reactive oxygen species in tumorigenesis, prevention, and therapy. Antioxid Redox Signal 16 1295-1322. Link: https://bit.ly/2yaDwaE

17. Gibbons DL, Byers LA, Kurie JM (2014) Smoking, p53 Mutation, and Lung Cancer. Mol Cancer Res 12: 3-13. Link: https://bit.ly/3bGz0OP

18. Tao Qu, Zhang J, Xu N, Liu A, Li A, et al. (2019) Diagnostic value analysis of combined detection of Trx, CYFRA21-1 and SCCA in lung cancer. Oncol Lett 17: 4293-4298. Link: https://bit.ly/36aloua

19. Zhao W, Yu H, Han Z, Gao N, Xue J, et al. (2015) Original Article Clinical significance of joint detection of serum CEA, SCCA, and bFGF in the diagnosis of lung cancer. Int J Clin Exp Pathol 8: 9506-9511. Link: https://bit.ly/2TfQ9so

20. Zou Y, Wang L, Zhao C, Hu Y, Xu S, et al. (2013) CEA, SCC and NSE levels in exhaled breath condensate--possible markers for early detection of lung cancer. J Breath Res 7: 047101. Link: https://bit.ly/2LBDFXN

21. Ye S, Chen X, Yao Y, Li Y, Sun R, et al. (2019) Thioredoxin Reductase as a Novel and Efficient Plasma Biomarker for the Detection of Non-Small Cell Lung Cancer: a Large-scale, Multicenter study. Sci Rep 9: 2652. Link: https://bit.ly/3g39gjk

22. Wojcik E, Kulpa JK (2017) Pro-gastrin-releasing peptide (ProGRP) as a biomarker in small-cell lung cancer diagnosis, monitoring and evaluation of treatment response. Lung Cancer 8: 231-240. Link: https://bit.ly/2Zfk1J1 
23. Obermayr E, Agreiter C, Schuster E, Fabikan H, Weinlinger C, et al. (2019) Molecular Characterization of Circulating Tumor Cells Enriched by $A$ Microfluidic Platform in Patients with Small-Cell Lung Cancer. Cells 8: pii: E880. Link: https://bit.ly/3bNahlY

24. Dong A, Zhang J, Chen X, Ren X, Zhang X (2019) Diagnostic value of ProGRP for small cell lung cancer in different stages; Journal of Thoracic Disease; J Thorac Dis 11: 1182-1189. Link: https://bit.ly/3fXErMI

25. Qi W, Li X, Kang J (2014) Advances in the study of serum tumor markers of lung cancer. J Cancer Res Ther. Link: https://bit.ly/2LGaNNW

26. Milman N, Pedersen LM (2002) The serum ferritin concentration is a significant prognostic indicator of survival in primary lung cancer. Oncol Rep 9: 193-198. Link: https://bit.ly/2ZfEgqa

27. Chana DL, Clarkea SJ, Diakosa Cl, Roach PJ, Bailey DL, et al. (2017) Simron Singhc, Nick Pavlakisa; Prognostic and predictive biomarkers in neuroendocrine tumours. Critical Reviews Oncology Hematology 113: 268282. Link: https://bit.ly/2WDyKvL

28. Portela-Gomes GM, Grimelius L, Wilander E, Stridsberg M (2010) Granins and granin-related peptides in neuroendocrine tumours. Regul. Pept 165: 12-20. Link: https://bit.ly/3g5mo7B

29. Wolin E, Castellano D, Kaltsas G, Gross D, Panneerselvam A, et al. (2011) Correlation of progression-free survival with early response of biomarkers chromogranin a and 5-Hydroxyindoleacetic acid levels in patients with advanced neuroendocrine tumors: phase III RADIANT-2 study Results NANETS (Abstr C29). Link: https://bit.ly/2zHOGUN

30. Petrović M, Bukumirić Z, Zdravković V, Mitrović S, Atkinson HD, et al. (2014) The prognostic significance of the circulating neuroendocrine markers chromogranin A, pro-gastrin-releasing peptide, and neuron-specific enolase in patients with small-cell lung cancer. Med Oncol 31: 823. Link: https://bit.ly/2TcUYm3

31. van der Horst-Schrivers AN, Post WJ, Kema IP, Links TP, Willemse PH, et al. (2007) Persistent low urinary excretion of 5-HIAA is a marker for favourable survival during follow-up in patients with disseminated midgut carcinoid tumours. Eur J Cancer Oxf Engl 43: 2651-2657. Link: https://bit.ly/3bKXg2d

32. Adaway JE, Dobson R, Walsh J, Cuthbertson DJ, Monaghan PJ, et al. (2016) Serum and plasma 5-hydroxyindoleacetic acid as an alternative to 24-h urine 5-hydroxyindoleacetic acid measurement. Ann Clin Biochem 53: 554-560. Link: https://bit.ly/3fXFb4z

33. Nistor C (2009) Carcinoidul traheo-bronşic. Editura Universitară Carol Davila 33-53.

34. Martin AM, Young RL, Leong L, Rogers GB, Spencer NJ, et al. (2017) The diverse metabolic roles of peripheral serotonin. Endocrinology 158: 10491063. Link: https://bit.ly/3dTEes8

35. Hofland J, Zandee WT, de Herder WW (2018) Role of biomarker tests fo diagnosis of neuroendocrine tumours. Nat Rev Endocrinol 14: 656-669. Link: https://bit.ly/2Tfkebz

\section{Discover a bigger Impact and Visibility of your article publication with} Peertechz Publications

\author{
Highlights \\ * Signatory publisher of ORCID \\ * Signatory Publisher of DORA (San Francisco Declaration on Research Assessment) \\ * Articles archived in worlds' renowned service providers such as Portico, CNKI, AGRIS, \\ TDNet, Base (Bielefeld University Library), CrossRef, Scilit, J-Gate etc. \\ * Journals indexed in ICMJE, SHERPA/ROMEO, Google Scholar etc. \\ * OAI-PMH (Open Archives Initiative Protocol for Metadata Harvesting) \\ * Dedicated Editorial Board for every journal \\ * Accurate and rapid peer-review process \\ * Increased citations of published articles through promotions \\ * Reduced timeline for article publication \\ Submit your articles and experience a new surge in publication services \\ (https://www.peertechz.com/submission).
}

Peertechz journals wishes everlasting success in your every endeavours.

Copyright: @ 2020 Nistor CE, et al. This is an open-access article distributed under the terms of the Creative Commons Attribution License, which permits unrestricted use distribution, and reproduction in any medium, provided the original author and source are credited. 